
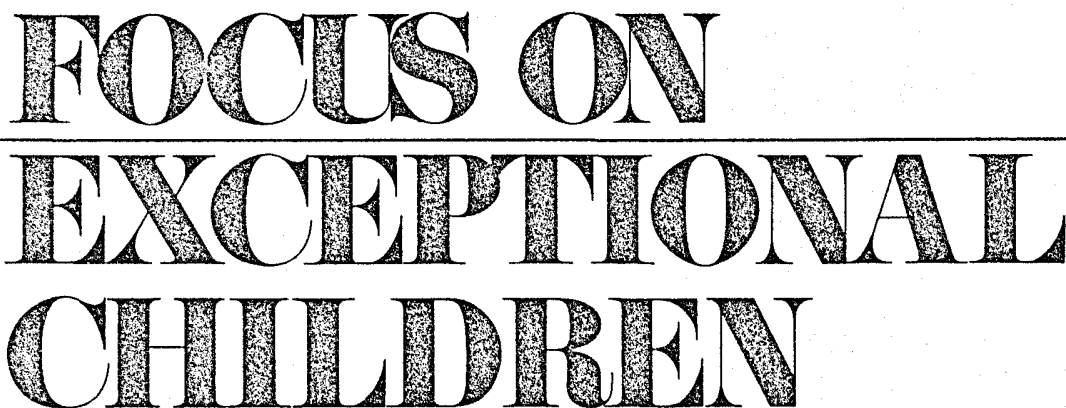

\title{
Composition Research and Practice: A Unified Approach
}

\author{
Steve Graham
}

Writing is an essential tool. It is used daily in business and is a common means of personal communication. Educationally, writing is the major medium by which students demonstrate their knowledge, and it is the primary instrument through which teachers evaluate performance. Composition is also a powerful tool for exploring thought and recording ideas. Finally, writing can fulfill emotional needs, and it offers a source of entertainment and enjoyment.

Despite the importance of written language, the National Council of Teachers of English (1975) has indicated that the overall writing achievement of American students seems to be diminishing over time. This policy statement reflects a growing concern on the part of the public, as well as numerous professionals (Odell, 1980), that our schools are not doing an adequate job of teaching composition.

This concern is not new. As early as 1901 , two members of the Department of English at Harvard University noted that a substantial number of students in the freshman program could not distinguish a sentence from a phrase or spell even the simplest words (Copeland \& Rideout, 1901). In any case, many students currently enrolled in American colleges unfortunately have not mastered the skills essential to effective writing (Meisterheim, 1977).

Although many possible reasons can be given for students' difficulty in learning to write, our present writing crisis is largely a teaching crisis. Students often do not write well because they have not been taught to write. An eminent language arts specialist, Strickland (1963), has suggested that composition is one of the most poorly taught elements of the elementary and secondary school curriculum. In general, teachers are not adequately prepared to teach composition, nor do they enjoy writing themselves (Graves, 1978). In fact, the teaching of writing appears to receive only a limited amount of instructional time (Edmund, 1957a; Graves, 1978; Hoetker \& Brossell, 1980; Pave, 1979; Shanahan, 1979).

One group of students who could benefit greatly from improvements in the teaching of writing encompasses mainstreamed handicapped students. From elementary school to college, learning disabled students score significantly lower than normal students on a variety of written language tasks (Hemreck, 1979; Moran, 1981; 
Moran \& Vogel, in press; Myklebust, 1973; Poplin, Gray, Larsen, Banikowski, \& Mehring, 1980; Poteet, 1979). Similar differences have been observed between retarded and nonretarded students (Cartwright, 1968; Durrell \& Sullivan, 1958; Sedlak \& Cartwright, 1972; Sterrett, 1965.) If a study by Leinhardt, Zigmond, and Cooley (1980) is representative, handicapped students may also spend less than 10 minutes a day generating written language!

This article presents a model of writing instruction based on a foundation of both research evidence and experiential knowledge. Although the model deals mainly with the instructional and curricular components of teaching writing, the complexities inherent in written representation and the predelictions the learner brings to the task are also considered. The model is designed for mainstreamed handicapped students but could be adapted for use with most school-age children.

\section{DEVELOPMENT OF WRITTEN LANGUAGE}

Writing depends in part upon the overall development in language and cognition. It is a demanding task requiring conscious persistence, flexibility, and highlevel thinking skills. Proficient writing necessitates the ability to monitor and direct the composing process,

FOCUS ON EXCEPTIONAL CHILDREN (ISSN 0015-5IIX) (USPS 203-360) is published monthly except June, July, and August as a service to teachers, special educators, curriculum specialists, administrators, and those concerned with the special education of exceptional children. This journal is abstracted and indexed in Exceptional Child Education Resources, and is also available in microform from Xerox University Microfilms, Ann Arbor, Michigan. Subscription rates, $\$ 15.00$ per year. Copyright 1982, Love Publishing Company. All rights reserved. Reproduction in whole or part without written permission is prohibited. Printed in the United States of America. Second class postage is paid at Denver, Colorado. POSTMASTER: Send address changes to:

$$
\begin{gathered}
\text { Love Publishing Company } \\
\text { Executive and Editorial Office } \\
1777 \text { South Bellaire Street } \\
\text { Denver, Colorado } 80222 \\
\text { Telephone (303) 757-2579 }
\end{gathered}
$$

\section{EDITORIAL BOARD}

Edward L. Meyen University of Kansas
Glenn A. Vergason Georgia State University

Richard J. Whelan

University of Kansas Medical Center
Carolyn Acheson

Senior Editor
Stanley F. Love Publisher while more-or-less simultaneously dealing with a large number of constraints (e.g., mechanics, purpose, organization, clarity, textual connections). This requires the coordination and automatization of a vast array of skills. Futhermore, writing is commonly directed at an absent other. A writer often has to compose a message to an unknown person who is unfamiliar with the topic and will not read the selection until a later date. As Moffett (1968) indicated, the demands placed on the writer increase as the distance and time between sender and receiver increase.

According to Hayes and Flower (1980), mature writing consists of three major processes: planning, translating, and reviewing. The purpose of the planning process is to organize relevant information and to develop a writing plan that will satisfy the writer's goals. Planning includes three subprocesses: generating (retrieving relevant information), organizing (structuring useful information either temporally or hierarchically), and goal setting (developing goals and establishing a writing plan to meet those goals). The second major process, translating, transforms relevant information, under the guidance of the writing plan, into acceptable written English. The function of the third process, reviewing, is to improve the quality of the material written. Language usage, accuracy of meaning, and accomplishment of the writer's goals are refined and polished by two subprocesses: reading and editing.

The description proposed by Hayes and Flower is particularly useful because it accounts for individual differences and allows for a complex interaction of processes and subprocesses. To illustrate, an author could produce an essay by any of the following procedures. One, the writer might decide to simply write thoughts down as they occur and revise them later. Two, the author might attempt to produce a perfect first sentence, followed by a perfect second sentence, and so on. Three, the composer might in successive order plan, write, and edit the essay. Regardless of which plan is chosen, the various processes will probably be interrupted by other processes and subprocesses. For example, production of the written text may be temporarily punctuated by the incorporation of new ideas, review, reformulation, or reorganization.

Bereiter (1980) indicated that mature writing consists of at least six different skills: fluency in generating ideas, fluency in producing written language, mastery of writing conventions, facility in considering the reader, literary appreciation, and reflective thought. Since these systems may develop simultaneously at different rates and, to a greater or lesser extent, independently of each other, development of written language does not neces- 
sarily follow a fixed sequence. Rather, writing development may follow what Schaeffer (1975) called "hierarchic skill integration." Because beginning writers cannot integrate all skills at once, they integrate those they can. As these skills become automatized, they integrate other skills to achieve a functional skill of a higher order.

\section{Models of Composition}

To describe the development of written language, several models of composition have been proposed (see Bereiter, 1980; Britton, Burgess, Martin, \& Rosen, 1975; Whale \& Robinson, 1978). Of these, the system devised by Bereiter (1980) best illustrates the concept of hierarchic skill integration. The model includes five stages. The first mode, associative writing, consists of writing down whatever comes to mind and entails fluency in generating ideas and producing written language. The second mode, performative writing, involves integrating children's spontaneous writing with knowledge of stylistic conventions. Communicative writing, the third mode, combines performative writing with social cognition (i.e., the ability to adapt messages to the characteristics of the intended audience). Fourth, unified writing incorporates the writer's personal viewpoint. And fifth, epistemic writing emerges when the author is able to employ writing as a tool for exploring and extending thought. Although these stages are for the most part distinct, they could be ordered differently. For example, various authors have indicated that they have successfully bypassed performative writing (Elsasser \& John-Steiner, 1977; Jacobs, 1970; Kohl, 1967; Pettigrew, Tefft, \& Van Nostrand, 1977).

\section{Selected Research}

Although written language tends to become more complex with age and experience (Hunt, 1965; LaBrant, 1933; McCarthy, 1954; O'Donnell, Griffin, \& Norris, 1967), growth in the mastery of writing skills is not regular. According to the National Assessment of Educational Progress (1975), students often demonstrate substantial gains in writing quality between the ages of 9 and 13 but little or no gain between 13 and 17 . Similarly, mastering writing conventions may evidence uneven and unstable trends. To illustrate, Hunt (1965) indicated that the average length of sentences and the average number of words per clause demonstrated optimum growth between grades four and eight, and the ratio of clauses per $\mathrm{T}$-unit developed most rapidly between grades eight and twelve. Additionally, Bear (1939) found that run-on sentences became more frequent during the middle grades. Such errors may increase with age because students generally attempt to introduce new skills and use more complicated forms of expression (Bereiter, 1980; Diebel \& Sears, 1917; Meckel, 1963).

The ability to employ literary devices and adapt written messages to the characteristics of the intended audience also does not appear to follow a fixed sequence of development. For instance, Hill (1972) observed that even though literary devices could be found in the writing of children of all ages, no specific pattern of development was evident. Moreover, students are usually not able to appreciably adapt their written messages for an intended audience until they reach high school or college (Bracewell, Scardamalia, \& Bereiter, 1978; Crowhurst, 1977; Smith \& Swan, 1978; Scardamalia, Bereiter, \& McDonald, 1977).

To summarize, development in written language can be characterized by spurts, plateaus, and even regressions. Although some discernible growth occurs from one grade to the next (Barbig, 1969; Heed, 1956); Schonell, 1942), different skills develop at different rates. Therefore, students not surprisingly demonstrate substantial variations in the acquisition of specific writing skills (Adams, 1937; Ash, 1935; Ford, 1954; Schonell, 1942; Witty \& Martin, 1957).

Finally, development in written language may be affected by both genetic and environmental factors. Achievement in written composition has been found to be related to school locale (Coutts \& Baker, 1955; Geoghegan \& Fitzgerald, 1935; Wheeler, 1940), SES (McClellan, 1956; Van Bruggen, 1946), personality characteristics (Mann, 1944; Patten, 1950), maturity (Meckel, 1963), reading achievement (Barbig, 1969; Cochrane, 1956; Maloney, 1968), oral language development (Loban, 1963), intelligence (Ford, 1954; Huxtable, 1929; Lorge \& Kruglov, 1951; Swenson \& Caldwell, 1948; Wilson, 1963), and sex (Baker, 1954; Berse, 1974; Donelson, 1967; Graves, 1973; Graves, 1975; Golub \& Frederick, 1970; Littwin, 1935; Martin, 1970; May \& Tabachnick, 1966; Stalnaker, 1941; Woodward \& Phillips, 1967).

\section{EFFECTIVENESS OF SELECTED INTERVENTIONS}

The preceding discussion points out that writing is multifaceted and requires mastery of a variety of skills. As a result, several distinct methods for developing writing ability have been advocated. For purposes of 
clarification and discussion, these instructional procedures have been classified as either direct or indirect approaches.

\section{Direct Approaches}

Graves (1978), Koch (1970), and Moffett (1968), among others, have advised that the best way to teach writing is to simply let students write. The critical assumption underlying this recommendation is the belief that spontaneous writing is an effective vehicle for increasing written fluency and gathering raw material for later, more structured writing (Emig, 1971; Macrorie, 1970). Although this rather straightforward "think-itwrite-it" approach has a comforting simplicity, empirical evidence is lacking to directly support the contention that writing in and of itself will produce better writers. Several investigators have found that merely increasing a student's amount of writing does not necessarily result in improved writing performance (Burton \& Arnold, 1963; Christiansen, 1964; Dressel, Schmid, \& Kincaid, 1952; Edmund, 1963; McColly \& Remstad, 1963; Sutton \& Allen, 1964). Without proper motivation or careful instruction, frequent spontaneous writing may be, in many instances, of limited value (Braddock, 1969).

\section{Pre-write, Write, Re-write}

An interesting alternative to the "think-it-write-it" procedure is the "pre-write, write, and re-write" model. This approach divides the composition process into a series of relatively discrete stages (see Myers, 1978). During the pre-writing step, various techniques are used to help students generate ideas and develop a writing plan. Next, students transform their ideas into written text. Finally, students rewrite or revise their original draft. The primary value of this model is that it stresses the importance of editing and it legitimizes thinking as a preliminary facet to writing.

Even though empirical support for this procedure is meager, researchers have found that initial planning is beneficial for some students (Beeker, 1969; Van Bruggen, 1946) and that a carefully designed sequence of writing and revision can result in writing improvement (Buxton, 1952; Fellows, 1932; Kraus, 1959; Maize, 1954; McColly \& Remstad, 1963). Despite the obvious advantages of this approach, mature writing typically involves a complex intermixing of planning, writing, and editing and, thus, may not necessarily proceed through a series of discrete successive stages (Flower \& Hayes, 1980). Many good writers also do not appear to spontaneously plan (Emig, 1971; Stallard, 1974) or revise their written products (Bracewell et al., 1978; Stallard, 1974).

\section{Modeling}

Another direct approach, modeling, has been a traditional staple of composition and rhetoric texts. This procedure is based on the assumption that students can readily imitate a particular style or technique embodied in a selected or developed writing sample. Students may be asked to mimic a specific sentence pattern, a wellknown writing style, a particular type of paragraph, and so on. For example, Laird, Gorrell and Pflug (1963) treated topic sentence development by presenting an example of a poor topic sentence with several good examples, followed by an analysis of the strengths and weaknesses of each. Suberman and Rosenberg (1963), on the other hand, asked students to write their own paragraphs after first locating topic sentences in several model paragraphs.

How effective is modeling? Rothstein (1970) found that programmed learning was more effective and efficient than modeling. Sponsler (1971) indicated that models may have no significant impact upon improvement of overall composition skills. Schiff (1978) concluded that a problem-solving approach to modeling works as well as or better than a procedure that emphasizes stategy explanation and model illustration. Although empiricial research, albeit limited, does not support the efficacy of the overall modeling approach, some methods of modeling may be more effective than others.

\section{Indirect Approaches}

Indirect approaches, in contrast to direct methods, typically attempt to improve writing ability by further developing or refining a student's reading, oral language, and grammar skills. The critical assumption underlying these procedures is that reading, writing, and language are closely related and function in an interactive and supportive way. By increasing and varying oral language experiences, for instance, teachers have often been led to believe that their students will more likely achieve writing success (Groff, 1978). Nonetheless, language arts specialists disagree as to the precise benefits of indirect training on the development of a student's skill in written composition. Because expert opinion on this matter varies, relevant research should be examined in an attempt to resolve this dispute. 


\section{Reading}

Reading is obviously an essential aspect of good writing. The process of gathering information, reviewing what has accumulated, and editing are all, to some extent, dependent upon reading proficiency. Nevertheless, learning to write and learning to read may entail the development of unique skills or similar skills that evolve in different patterns. For instance, Shanahan (1981) found that although reading and writing are significantly related at the second and fifth grade levels, the nature of this relationship changes over time.Furthermore, the correlation between these two factors was found to account for less than 50 percent of the variance in writing and reading achievement.

The critical question, however, is whether reading instruction does or does not contribute to children's writing achievement. Christiansen (1964), Elkins (1968), Heys (1962), and Schneider (1970) concluded that a combination of reading and writing worked as well as frequent writing or conventional writing instruction. Smart and Ollila (1978) found that students receiving recreational reading plus patterned writing practice made equivalent gains in syntactical maturity when compared with a group of students who completed sentence-combining exercises. Elkins (1968), Mathews, Larsen, and Gibbon (1945), and Wheeler (1965) discovered that extensive and analytic reading and discussion were no more effective than frequent writing or conventional writing instruction. Taken as a whole, research examining this question suggests that from junior high school to college, a combination of reading and writing may be as effective as traditional instruction. This generalization applies primarily to good readers. A serious attempt to improve a poor reader's writing skills through reading instruction may be unsuccessful.

\section{Oral Language}

Oral language is commonly believed to be the foundation upon which written language is developed. Research by Loban (1963) and Heider and Heider (1941) indirectly supports this position. Loban (1963) reported that the oral language and written language of sixthgrade children were interrelated. Superior writers received an oral language rating of 4.08 , good writers a rating of 3.52, inferior writers a rating of 3.01, illiterate writers a rating of 2.61 , and primitive writers a rating of 2.53. Heider and Heider (1941) found that the written language of deaf students (children with poor oral language) resembled the written language of younger child ren with normal hearing. Although these two studies support the notion that oral and written language are interactive, one cannot clearly tell whether they are simply correlated or casually related.

During the primary grades children usually do not write what they cannot say (Groff, 1978). Research by Eldredge (1965), Howell (1956), and Wilson (1963) revealed that young children's spoken language was generally more complex than their written language. Nonetheless, somewhere during the middle school years this difference reverses. Written language becomes more fluent and complex (Bavery, 1968; Bushnell, 1930; Golub, 1968; Harrell, 1957; Martellock, 1971; McLean, 1964; O'Donnell et al., 1967; Simmons, 1963) and less prone to errors (Bushnell, 1930; Lemon \& Buswell, 1943; Poteet, 1979). Futhermore, bilingual children usually write as well as monolingual children (Lewis \& Lewis, 1965; Rodrigues, 1974), and the written language of nonstandard English speakers more closely approximates standard English than does their oral production (DeStefano, 1972; Kono, 1972; Raybern, 1974). These children apparently do not write as they speak. Thus, for older students, oral language does not provide a successful model for written production.

Several authors have emphasized that oral language activities or training should be an integral part of the writing program (Emig, 1971; Golub, 1974; Graves, 1978). Research examining this proposition, however, is not conclusive. Beidler (1969) and Wiggins (1968) found that generalized language training does not have a significant impact on a student's written language. Nevertheless, specific types of oral drill may influence selected aspects of a child's writing. Beeker (1969) reported that oral discussion prior to the writing task was beneficial for some fifth-grade students. Also, by fourth grade, oral sentence-combining exercises appear to positively affect the complexity and quality of a child's writing (Combs, 1975; O'Hare, 1973; Mellon, 1969; Miller \& Ney, 1968). The success of these exercises, though, may result primarily from their ability to reduce the complexity of the writing task. Therefore, the bulk of the evidence does not support the position that extensive oral language training results in improved writing.

\section{Grammar}

One of the most consistently held beliefs in the history of education is that the systematic teaching of grammar and usage is an important part of writing instruction. An abundance of research and experience over the past 80 years, however, has failed to validate this assumption (Blount, 1973; Braddock, 1963; Braddock, Lloyd-Jones, 
\& Schorer, 1963; LeFevre, 1970; Meckel, 1963). Knowledge of grammatical concepts does not appear to be a necessary prerequisite for skillful use of written language. Furthermore, formal grammar is difficult to master and is, in comparison to other techniques, less effective in facilitating written language development.

Mixed results have been obtained concerning the effectiveness of more recent grammars. Although some students appear to be able to master the concepts embodied within structural and transformational grammar as early as fifth grade, evidence is inconclusive as to whether these approaches are more effective than traditional grammar or have an appreciable effect on improving writing skills. Since instructional skills mastered in one domain cannot be assumed to automatically transfer to another domain (Keogh \& Glover, 1980; Meichenbaum, 1980 ), the wisdom of having handicapped students memorize highly complex rules is questionable. Rather, improvement of usage may be more effectively achieved through direct practice of desirable forms when the need arises. For example, the ability to write complex sentences can, under teacher guidance, be developed directly by having students combine, manipulate, and rearrange two or more related simple sentences. To ensure mastery and generalization, practice should be repeated and spaced, and the student should be encouraged to apply newly learned skills in actual writing situations.

In summary, generalized instruction in the areas of reading, oral language, and grammar appears to be of limited value in the immediate improvement of a student's writing. Thus, even though language skills are interrelated, they are not necessarily reciprocal. Nonetheless, specific activities such as sentence-combining exercises or selected language experiences prior to writing can be beneficial.

\section{INSTRUCTIONAL RECOMMENDATIONS}

No one best method or technique has emerged for teaching composition. None of the methods presented provides a program broad enough to encompass the totality of the writing process or the diverse needs of handicapped students. Since different interventions often influence different aspects of performance (Graham \& Madan, 1981), a combination of direct and indirect approaches should prove to be advantageous. A program based on such an eclectic model should be systematic, teacher-directed, individualized, and flexible. It should also be founded on the following principles and conditions:
One: Students should be exposed to a broad range of writing tasks.

Students need to be given plenty of opportunities to write and should experience a variety of practical, imaginative, and creative assignments. Activities should include, but not necessarily be limited to: descriptions, directions, running commentaries, messages, greeting cards, personal letters, business letters, imaginative stories, summaries, diaries, announcements, reports, outlines, autobiographies, biographies, advertisements, reviews, job applications, note taking, check writing, editorials, simple plays, jokes, poetry, essay tests, and dictation. Depending upon the characteristics of the student and the severity of the handicapping condition, teachers may wish to add or delete specific types of assignments.

Since writing assignments are apparently an important part of teaching composition, great care must be taken in their selection and presentation. The literature on teaching composition suggests that assignments should be: (1) appropriate to the age and skill level of the child, (2) interesting, (3) generally aimed at an authentic audience, (4) designed to serve a real purpose, and (5) carefully planned and coordinated so the scope and complexity of similar forms can be gradually increased. Additionally, students need ample time to complete assignments, and teachers should try to create an atmosphere conducive to good writing. The latter is particularly important since writing produced under stressful conditions is usually lower in readability and higher in mechanical errors (Bettinghaus \& Preston, 1964; Bradley \& Tannenbaum, 1962). Even something as innocuous as background music can, under certain circumstances, inhibit the quantity and quality of a student's written language (Donlan, 1976). The classroom, therefore, should be supportive, nonthreatening, informal, and free from major distractions.

The success of some assignments appears to be closely related to teacher directions, choice of topics, and source of stimulation. For instance, Kraetsch (1981) found that the written output of a 12-year-old student could be increased by simply asking the student to write "as many words as you can." Writing performance can further be influenced by the significance of the situation and the intended purpose of the message (Perron, 1979). Consequently, teacher instructions should specify why and for whom the assignment is being written.

The topic the student is asked to write about can also influence the quantity and quality of the written response (Crowhurst, 1977; Johnson, 1967; Nelson, 1965; San Jose, 1972; Stewart, 1978). As might be expected, a student's performance is usually better if the assignment 
is a topic of interest (Sofell, 1929). Fortunately, most students have a wide range of interests (Edmund, 1958a).

Although most children are capable of choosing topics independently, Edmund (1957b) indicated that more than half of the seventh-grade students he surveyed had never been responsible for selecting their own writing assignments. This is somewhat surprising since some empirical support exists for encouraging students to write about their own personal interests and needs (Clark, 1954; Sofell, 1929). When permitted to choose their own topic, however, students do not typically write about their stated personal interests (Edmund, 1958a). The findings from these studies suggest that teachers should help students identify and develop their interests and should periodically allow children to select their own topics.

Writing is hard work and requires having something to write about. As a result, teachers have used a variety of stimuli for motivational purposes and to help students develop writing content. Idea-stimulating activities or objects include pictures, reading selections, music, listening experiences, trips, story outlines, newsworthy events, paintings, story titles, television, dance, cartoon characters, movies, and holidays.

Even though the evidence is not conclusive, certain types of experiences or activities prior to writing may be more effective than others. Edmund (1958b, 1958c, 1959) and Wyatt (1961) concluded that students wrote more creatively from derived experiences (those encountered in reading, television, radio, and so forth) than from direct personal experience. Carlson (1963) and Howell (1956) indicated that stimuli such as pictures, toys, and books were more conducive to writing success than were story titles. Littwin (1935) found that firsthand experiences (i.e., multisensory) were more effective in developing imagination than were vicarious experiences (e.g., picture study). Other researchers have not found a significant relationship between the source of stimulation and the quality of children's writing (Berse, 1974; Berry, 1958; May, 1966).

Based on the evidence presented, teachers probably should employ a variety of idea-stimulating activities and experiences. Stimuli should be carefully selected since research indicates that students may respond differentially to selected aspects of similar objects. For example, Poteet (1979) indicated that children write fewer words in response to outdated pictures and Golub (1970) concluded that black-and-white concrete pictures were better story starters than black-and-white abstract, color concrete, or color abstract pictures.

Two: Strategies for reducing the number of cognitive demands inherent in the act of writing should be an integral part of a remedial composition program.
Turning thoughts into written language is a demanding task. The writer must be able to draw upon a variety of mental operations in order to deal with the generation and organization of ideas, sentence and paragraph construction, and rhetorical considerations. This requires the automatization of a large number of skills operating at different processing levels. "A writer caught in the act looks ... like a very busy switchboard operator trying to juggle a number of demands on her attention and constraints on what she can do" (Flower \& Hayes, 1980, p. 33).

Collins and Gentner (1980) indicated that a writer must successfully manage three basic constraints. One, loosely related ideas and information must be transformed into an organized network of knowledge. Two, the body of the text must conform to the conventions of usage and the rules of grammar. Three, writers must consider their purpose, their audience, and their projected roles. Trying to satisfy all three of these demands at one time places an enormous strain on the writer's attention and memory. Beginning and poor writers, in particular, are not able to manage all of these constraints simultaneously. Fortunately, several strategies can be used to help students reduce the number of cognitive demands inherent in the act of writing. Cognitive strain can be diminished through the use of instructional aids, partitioning, and automatization.

Instructional aids. Beginning and poor writers must focus their attention on the ideas they wish to convey, while remaining keenly aware of skills such as spelling, handwriting, and sentence construction. For these students, complex thoughts don't automatically blossom into correspondingly and appropriately complex written language. As a result, teachers have often relied on external aids as one way to minimize the effect of poor writers' less-than-automatic writing skills.

The most commonly used external aid for overcoming the encumbering effects of structural constraints is dictation. Most young children's first compositions are dictated to the teacher. In essence, the child furnishes the ideas and the teacher structures the form the material takes on paper. As the student becomes more and more adept with the mechanics of writing, the teacher's role as a scribe diminishes correspondingly.

Studies by several researchers support the efficacy of dictation with young children (Howell, 1956; Shaw, 1934; Waldschmidt, 1973; Wilson, 1949). Although similar research with handicapped students is lacking, many teachers have successfully used this strategy in special education classrooms. In addition, Gould (1980) has found that college students were able to learn how to dictate effectively with only a limited amount of practice. 
Thus, dictation may be a viable alternative to writing for students of normal intelligence who, after years of intensive instruction, have not been able to automatize and integrate basic writing skills.

An interesting adaptation of the conventional dictation process involves the use of tape recorders to organize written content (Zanotti, 1970). Once materials are taped, they can be written and edited by the student, the teacher, a peer, or a combination thereof. Under most circumstances, however, dictation is a temporary aid and, futhermore, students should be given opportunities to both write and dictate compositions.

Visual aids provide another means for circumventing the structural stumbling blocks that often obstruct children's written expression. For example, Barnes (1964) gave 45 second-grade students 60,000 șmall word cards and 100 grooved boards for use in assembling words into sentences. After four months these children wrote longer stories, used a wider variety of words, and displayed more imagination than did the controls. In a different experiment, Oftedal (1948) had 25 third-grade children plan, organize, and record their stories on drawing paper folded into sequential parts. The picturewritten stories were superior to handwritten stories in originality, vocabulary, and length.

Partitioning. Breaking down a large, complex problem into semi-independent subproblems is a powerful means for reducing cognitive strain (Flower \& Hayes, 1980). Most poor and even many good writers cannot deal with the topic, text, and intended audience all at once. The complexity of the problem can be reduced by initially ignoring one or more of these constraints. For example, students could be asked to write a set of directions for a younger student. At first they might choose to write the directions in sequential order. Later, they might rewrite the instructions so they are comprehensible to younger children.

A second means of partitioning the writing task is to separate the process into producing ideas and producing text for those ideas. This is the primary postulate underlying the "pre-write, write, and re-write" model of composition. Silverman, Zigmond, Zimmerman, and Vallecorsa (1981) have described a stage-writing model designed specifically for handicapped students. According to this model, the teacher first structures the writing assignment with pre-writing activities that involve thinking, experiencing, discussing, and interacting with language. The teacher and the student then conjointly generate a series of questions that are used to guide the writing process. During the post-writing phase, the teacher critiques the student's writing positively, and the student and the teacher prepare the composition for final form. The authors reported that this procedure has been used successfully with learning disabled students.

Planning. Another important technique for reducing cognitive strain is planning. Planning not only reduces constraints, but it also integrates them (Hayes, 1978). Composition plans are of three basic types. First, "plans to do" enumerate the constraints the students must deal with. Second, "plans to say" are essentially simplified or abstracted versions of the writing content and are analogous to outlining. Third, "composing plans" specify the steps by which students guide themselves through the writing proces.

Automatization. A final means of reducing cognitive strain is to make certain subtasks so automatic that they require only a minimal amount of conscious attention. This opens up processing space in short-term memory and allows the writer to focus his or her attention on other important factors. For instance, development and integration of the lower-level skills of getting language onto paper enables students to deploy more of their attention to higher-order processes such as purpose, content, or organization. Teachers should help students automatize and integrate:

- handwriting and spelling.

- construction of sentences, paragraphs, and longer forms of discourse.

Although handwriting and spelling are subskills of written composition, they should be taught, for the most part, during a separate period. Moreover, instruction should be direct and not incidental. After selected skills are developed, students need considerable practice in using these skills in context (i.e., writing). Graham and Miller $(1979,1980)$ have developed a hand writing and a spelling program based on these principles.

Practice designed to help students gain efficiency in manipulating sentences, paragraphs, and longer forms of discourse should be based upon the flexible use of a wide variety of techniques and methods. Furthermore, students do not learn to write effectively by first mastering sentences, then paragraphs, and later essays. Instead, a newly learned concept is initially reinforced and subsequently refined and extended.

As early as 1929, Poley reported a high correlation between variety of sentence structure and excellence in composition. Results from this study provide some support for the traditional practice of teaching at least three basic sentence patterns: simple, compound, and complex. Christensen (1968), however, has noted that many modern writers rely heavily on the simple sentence embellished with free sentence modifiers (i.e., preposi- 
tional phrases, adjective clusters). Thus, teachers should help students learn to vary both sentence variety and texture. These skills can be developed through sentencecombining exercises, modeling, arranging and rearranging word cards, or by completing sentences from which specific words or phrases have been deleted.

Basic paragraphs are of several different types. For example, a topic sentence may be followed by supporting details, or the details may precede the topic sentence. The topic sentence may be absent or sandwiched between two or more sentences. The most common means of teaching construction of these types of paragraphs is modeling. Students are first exposed to a particular type of paragraph and then asked to write paragraphs of their own. An interesting adaptation of this procedure has been suggested by Schiff (1978). First, students were given randomly arranged sentence strips and asked to rearrange them. Second, they analyzed their arrangement decisions by answering a series of questions. Third, their arrangement and the arrangement of the original author were compared and contrasted. Finally, the student wrote one or two paragraphs similar to the original model.

The construction of longer forms of discourse depends, in part, upon the student's ability to use organizational devices. For instance, a poor writer who has never written a business letter will probably lack a specific scheme for this genre. This means that a great deal of time will have to be spent planning and developing an appropriate structure. If the student had been able to draw upon a well-learned routine, more energy could have been devoted to refining and revising the final product. Thus, students should be taught how to present information chronologically, spatially, and in list form. They also need to learn the basic structures for business letters, short stories, letters of recommendation, reports, outlines, announcements, and similar items.

Three: Writing error should not be overemphasized.

Communication, not etiquette, is the main purpose of writing. Although teachers should expect neat and attractive work, the value in circling every misspelled word, red-marking each deviation from standard English, or writing "AWK" above every clumsy wording is minimal. Available research tends to support this position. Studies by Burton and Arnold (1963) and Fellows (1932) revealed that intensive evaluation has little or no effect on writing improvement. In fact, intensive concentration on students' errors may make them more aware of their limitations and less willing to write.

Only the most frequent and flagrant errors that appear in the child's writing should be treated. Instruction should further be restricted to errors that tend to obstruct the flow and effectiveness of thought. Of these, a few can be appropriately dealt with during the process of revision. Others should be treated after the writing assignment is completed. In any case, instruction should be direct and should emphasize the construction of desirable forms.

Prominent errors can be presented via the blackboard, tape recorder, opaque projector, written annotations, student-teacher conference, and so on. Student feedback should be explanatory, specific, and include suggestions for making corrections. Only one or two types of errors should be pinpointed at any one time.

Four: The composition program should be both pleasant and encouraging.

Positive attitudes are crucial to writing improvement. As most teachers know, students will not endure the struggle of translating thought into written language for teachers who do not appreciate the struggle or the results. The success of any writing program depends greatly upon the student's interest and motivation. Regrettably, many students do not enjoy writing and may experience high levels of anxiety when writing is required (Daly, 1977, 1978; Edmund, 1957a; Elkins, 1968). Since attitudes and methodology are intrinsically bound together, techniques to foster motivation should be an integral part of the total composition program.

How can a teacher promote positive attitudes toward composition? First, the teacher must be accepting and encouraging. For example, research investigators reveal that positive feedback can positively affect a student's writing (Beaven, 1977; Gee, 1970; Stevens, 1973; Taylor \& Hoedt, 1966). Apparently, writing will not deteriorate if criticism is withheld in favor of praise. Second, the student's success should be dramatized. Progress can be emphasized through the use of charts, graphs, verbal praise, and so on. Van Houten and McKillop (1977) found that timing, self-scoring, and the public posting of student performance were effective means of increasing written output. Third, rewards for good performance should be built into the composition program. And fourth, high interest activities involving functional writing should be emphasized whenever possible.

Five: The composition program should be planned, monitored, and modified on the basis of assessment information.

Assessment is integral to instruction in composition. Examination of the student's present level of performance, strengths and weaknesses, unique learning needs, and progress is necessary for formulating, implementing, and evaluating an effective program (Hudson \& Graham, 1978). A suitable analysis should be based on the following principles: 
1. Assessment should focus on both the written product and the writing process.

2. A variety of both standardized and informal procedures should be used.

3. Results of various assessments should not be considered as discrete, separate entities but should be analyzed for possible relationships.

General considerations. At least four factors can influence the accuracy of writing assessment. One, the validity and reliability of an assessment technique can be affected by how precisely the variables to be measured are defined. Nonetheless, considerable disagreement exists among teachers as to the nature of good writing.

In a study by Diederich, French, and Carlton (1961), professionals from six different fields rated compositions produced by college freshmen. These judges received no special instructions and were not asked to rate the papers on any particular quality. As expected, the researchers found that the judges did not agree with each other in their overall ratings. The written comments supplied by each judge revealed that they were affected differentially by the following elements: ideas, mechanics, organization, wording, and flavor. Thus, if variables are not precisely defined, teachers will likely respond to different elements within the same paper, or they may attach different weights to each factor.

A second major source of variability in writing assessment is the writer. The quality of a student's writing may evidence substantial variations from day to day or even within a single composition (Anderson, 1960; Kincaid, 1953). Moreover, an examiner cannot automatically assume that performance on a specific writing task adequately reflects a student's writing ability (Braddock et al., 1963). A headache, a cold, or distracting noises may cause the student to write below capacity.

A third variable that can affect the student's writing is the assignment. Performance may be influenced by: (1) the topic selected, (2) the mode of discourse, (3) the source of stimulation, (4) teacher directions, and (5) the intended audience. Also, the popularity of the proctor, the significance of the situation, the amount of time afforded for writing, and the lighting are among additional factors that can affect the quality of a student's response.

A final source of variability resides within the rater or judge. Extensive evidence suggests that grades assigned to essay papers tend to be unreliable (Diederich et al., 1961; McColly \& Remstad, 1963; Pooley, 1948; Starch \& Elliot, 1912). Different raters commonly assign different grades to the same paper, and a single rater may assign different grades to the same paper on two differ- ent occasions. If the assignment permits a wide range of possible responses, the process of grading essay papers is likely to be even more unreliable (Findlayson, 1951; Hartog \& Rhodes, 1936; Hwang, 1930; Noyes, 1963; Pearson, 1963; Vernon \& Millican, 1954).

A rater's consistency or reliability can be affected by several factors. One, fatigue may lead examiners to become severe, lenient, or erratic in their evaluations. Two, personal familiarity with the purpose for which the evaluation is being conducted can influence the severity or leniency of the teacher's rating. Three, an examiner may react consciously or unconsciously to different factors when evaluating a written composition. Regardless of content, teachers tend to assign lower grades to essays with:

- spelling and grammatical errors (Harris, 1977; Marshall, 1967; Scannell \& Marshall, 1966).

- handwriting of poor quality (Briggs, 1970; Chase, 1968; Huck \& Bounds, 1972; Klein \& Hart, 1968; Markham, 1976; Marshall \& Powers, 1969; McColly \& Remstad, 1965; Rondinella, 1963; Soloff, 1973).

Fortunately, reliability can be improved. By following specific guidelines and principles, teachers can make judgments that are both consistent and valid. Specific recommendations are:

1. The examination task should be highly structured. The topic, the mode of discourse, and the directions should be the same for all students.

2. Students should be given enough time to adequately complete an assigned topic. Primary grade children typically require at least 30 minutes, intermediate grade students as much as 50 minutes, junior high students 70 minutes, and high school students 90 minutes.

3. The assigned topic should be interesting, but at the same time difficult enough so that levels of excellence can be determined.

4. To control for the possible confounding effects of extraneous variables, identifying factors such as name, grade, and date should be removed from each paper. In some instances, the examiner may wish to have essays typed before grading them.

5. The consistency of an examiner's ratings can be improved through proper orientation, training, and practice. This can be achieved by two different means (McColly, 1970). One, examiners can be presented with a common set of predetermined criteria, and, two, readers can determine their own 
standards and criteria through consensus. Regardless of which approach is selected, practice is critical.

6. Essays should be read in solitude, and examiners should not grade papers for lengthy periods of time or late at night.

7. If possible, papers should be rated by two sets of readers.

8. Overall judgments are more likely to be valid if two or more samples are graded.

How can teachers judge whether the grades they assign to essays are reliable or consistent? Coffman (1976) has suggested a rather simple procedure for examining this question. The first step is to have students write a number instead of a name on their essays. $\mathrm{Next}$, the teacher rates each paper by whatever means has been used in the past. The ratings along with the identification numbers are recorded on a separate sheet of paper, and the essays are then put aside in a safe place. Several weeks later the teacher repeats the process. After the second rating is completed, the teacher counts the number of students who received different ratings. If the number is large, reliability is low; if the number is small, reliability is high.

Assessment techniques. Three basic techniques are involved in determining the quality of a student's writing. One of these, composition scales, consists of a carefully selected set of compositions, ranging in quality from, for instance, 1 to 8 . The examiner attempts to match the student's composition as closely as possible with one of the samples from the scale. The student's score on the composition scale is the number value of the most similar sample. Composition scales are not widely used today because (1) the student's composition is seldom similar to the sample compositions, and (2) different scales are often needed for different modes of discourse and different maturity levels (Braddock et al., 1963).

With the second approach, the holistic method, the examiner reads the student's essay to obtain a general impression of its quality (see Hogan \& Mishler, 1979). With this approach, the paper is to be read rapidly, and a score assigned on the basis of the examiner's instantaneous judgment. If examiners were given time to deliberate, irrelevant qualities (grammar, spelling, etc.) presumably might bias their judgment. Despite this precaution, some evidence indicates that mechanical errors may still influence a judge's rating (Harris, 1977; Healy, 1935).

A more complex procedure, the analytic method, requires that the examiner analyze and score each essay on several different factors, such as ideas, spelling, grammar, and flavor (see Carlson, 1979; Diederich, 1974). These mini scores are then averaged to produce a single grand score. Examiners, however, may not be able to independently deal with a number of different aspects within a single essay. Page (1968) found that ratings for different factors in the same paper evidenced high inter-correlations. This suggests that judgments on individual elements tend to collapse into a single rating. Teachers, can, in part, reduce this halo effect by rating question-by-question rather than student-by-student (Coffman, 1976).

Although the holistic method is less time-consuming than the analytic approach, research conducted during the past 30 years has revealed that the two methods yield about the same degree of reliability (Hogan \& Mishler, 1979). Nevertheless, little consensus has been reached regarding how many points or intervals a composition scale should consist of (see Healy, 1935; McColly, 1970; McColly \& Remstad, 1965). If a scale has only three gross levels, consistent ratings are obtained relatively easily. If a scale has 10 or more levels, it is likely to be more precise but less reliable. McColly (1970) also indicated that on odd-numbered scales, ratings tend to drift toward a convenient hypothetical midpoint.

\section{CONCLUSION}

An appropriate writing program for mainstreamed handicapped students requires collaborative planning and programming. The likelihood of writing success is increased if each of the participating teachers is assigned specific responsibilities for selected aspects of the proposed composition program. This requires that special and regular classroom teachers establish effective lines of communication, work together cooperatively, and coordinate their instructional plans (Graham, Hudson, Burdg, \& Carpenter, 1980; Hudson, Graham, \& Warner, 1979). The author, therefore, hopes that teachers will adapt the model presented in this article to their own particular students and situations.

\section{REFERENCES}

Adams, R. An experiment in the teaching of English composition. Journal of Experimental Education, 1937, 5, 339-342.

Anderson, C. The new STEP essay test as a measure of composition ability. Educational \& Psychological Measurement, 1960, 20, 95-102.

Ash, I. An experimental evaluation of the stylistic approach in teaching written composition in the junior high school. Journal of Experimental Education, 1935, 4, 54-62.

Baker, W. An investigation of characteristics of poor writers. College Composition on Communication, 1954, 5, 23-27. 
Barbig, E. An exploration of growth in written composition to determine the relationship of selected variables to poor writing in grades nine and twelve. Knoxville, TN: University of Tennessee, 1969. (ERIC Document Reproduction Service No. ED 034 782)

Barnes, D. An experimental study of written composition. Elementary English, 1964, 41, 51-52.

Bavery, E. A study of selected aspects of oral and written language of fifth grade pupils. Unpublished doctoral dissertation, University of Northern Colorado, 1968.

Bear, M. Children's growth in the use of written language. Elementary English Review, 1939, 16, 312-319.

Beaven, M. Individualized goal setting, self-evaluation, and peer evaluation. In C. Cooper \& L. Odell (Eds.), Evaluating writing: Describing, measuring, judging. Urbana, IL: National Council of Teachers of English, 1977.

Beeker, R. The effects of oral planning on fifth-grade composition. Unpublished doctoral dissertation, North Texas State University, 1969.

Beidler, A. The effects of the Peabody language development kits on the intelligence, reading, listening, and writing of disadvantaged children in the primary grades. Unpublished doctoral dissertation, Lehigh University, 1969.

Bereiter, C. Development in writing. In T. Gregg \& E. Steinberg (Eds.), Cognitive processes in writing. Hillsdale: Lawrence Erlbaum Assoc., 1980.

Berry. E. Film and creative expression. Elementary English, 1958, 35. 383-386.

Berse, P. Criteria for the assessment of pupils' compositions. Educational Assessment, 1974, 17, 54-61.

Bettinghaus, E., \& Preston, S. Dogmatism and performance of communicator under cognitive stress. Journalism Quarterly, 1964, $41,399-402$.

Blount, N. Research on teaching literature, language, and composition. In R. Travers (Ed.), Second handbook of research on teaching. Chicago, IL: Rand McNally, 1973.

Bracewell, R., Scardamalia, M., \& Bereiter, C. The development of audience awareness in writing. Paper presented at annual meeting of American Educational Research Association, Toronto, March 1978.

Braddock, R. English composition. Encvclopedia of Educational Research. New York: MacMillan, 1969.

Braddock, R., Lloyd-Jones, R., \& Schoer, L. Research in written composition. Champaign, IL: National Council of Teachers of English, 1963.

Bradley, G., \& Tannenbaum, P. Communicator performance under cognitive stress. Journalism Quarterly, 1962, 39, 169-178.

Briggs, D. Influence of handwriting on assessment. Educational Research, 1970, 13, 50-55.

Britton, J., Burgess, T., Martin, N., \& Rosen, H. The development of writing abilities. London: MacMillan Education, Ltd., 1975.

Burton, D., \& Arnold, L. The effects of frequency of writing and intensity of teacher evaluation upon high school students' performance in written composition. USOE Cooperative Research Report No. 1523. Tallahassee: Florida State University, 1963.

Bushnell, P. An analytic contrast of oral with written English. New York: Columbia University, 1930.

Buxton, E. An experiment to test the effects of writing frequency and guided practice upon students' skill in written expression. Unpublished doctoral dissertation, Stanford University, 1952.

Carlson, R. Recent research in originality. Elementary English, 1963, 40, 583-589.

Carlson, R. Sparkling words: Three hundred and fifteen practical and creative nriting ideas. Geneva, IL: Paladin House, 1979.

Cartwright, G. Written language abilities of educable mentally retarded and normal children. American Journal of Mental Deficiency, 1968, 72, 499-505.

Chase, C. The impact of some obvious variables on essay test scores. Journal of Educational Measurement, 1968, 5, 315-318.
Christensen, F. Notes toward a new rhetoric. New York: Harper \& Row, 1968.

Christiansen, M. The relative effectiveness of two methods of teaching composition in freshman English at Metropolitan Junior College. Unpublished doctoral dissertation, University of Kansas, 1964.

Clark, G. Writing situations to which children respond. Elementary English, 1954, 31, 150-155.

Cochrane, J. An analysis of the transition from high school to college in English composition in selected New York. State schools. Unpublished doctoral dissertation, University of Connecticut, 1956.

Coffman, W. On the reliability of ratings of essay examinations. In W. Mehrens(Ed.), Readings in measurement and evaluation in education and psychology. New York: Holt, Rinehart, \& Winston, 1976.

Collins, A. \& Gentner, D. A framework for a cognitive theory of writing. In L. Gregg \& E. Steinberg (Ed.), Cognitive processes in writing. Hillsdale: Lawrence Erlbaum Assoc., 1980.

Combs, W. Some further effects and implications of sentencecombining exercises for the secondary language arts curriculum. Unpublished doctoral dissertation, University of Minnesota, 1975.

Copeland, C., \& Rideout, H. Freshman English and theme-correcting in Harvard College. New York: Silver, Burdett \& Co., 1901.

Coutts, H., \& Baker, G. A study of the written composition of a representative sample of Alberta grade four and grade seven pupils. Alberta Journal of Educational Research, 1955, 1, 15-18.

Crowhurst, M. The effect of audience and mode of discourse on the syntactic complexity of the writing of sixth and tenth graders. Unpublished doctoral dissertation, University of Minnesota, 1977.

Daly, J. The effects of writing apprehension on message encoding. Journalism Quarterly, 1977, 54, 566-572.

Daly, J. Writing apprehension and writing competency. Journal of Educational Research, 1978, 72, 10-14.

DeStefano, J. Productive language differences in fifth grade students' syntactic forms. Elementary English, 1972, 49, 552-558.

Diebel, A., \& Sears, l. A study of common mistakes in pupils' written English. Elementary School Journal, 1917, 18, 172-185.

Diederich, P. Measuring growth in English. Urbana, IL: National Council of Teachers of English, 1974.

Diederich, P., French, J., \& Carlton, S. Factors in judgements of writing ability. Research Bulletin No. 61-15. Princeton, NJ: Educational Testing Service, 1961.

Donelson, K. Variables distinguishing between effective and ineffective writers in tenth grade. Journal of Experimental Education, $1967,35,37-41$.

Donlan, D. The effect of four types of music on spontaneous writing of high school students. Research in the Teaching of English, 1976, $10,116-126$

Dressel, P., Schmid, J., \& Kincaid, G. The effect of writing frequency upon essay-type writing proficiency at the college level. Journal of Educational Research, 1952, 46, 285-293.

Durrell, D., \& Sullivan, H. Language achievement of mentally retarded children. USOE Cooperative Research Report No. 014. Boston: Boston University, 1958.

Edmund, N. Story writing in the seventh grade. Elementary English, 1957, 34, 305-306. (a)

Edmund, N. What seventh graders write about. Elementary School Journal, 1957, 58, 129. (b)

Edmund, N. Do fifth grade pupils write stories on personal interests? Peabody Journal of Education, 1958, 36, 151-158. (a)

Edmund, N. Relationship between prior experiences and the creative quality of stories of fifth grade children. Elementary English, 1958, 35, 248-249. (b)

Edmund, N. A study of the relationship between prior experience and the quality of creative writing done by seventh-grade pupils. Journal of Educational Research, 1958, 51, 481-492. (c)

Edmund, N. Writing in the intermediate grades. Elementary English, 1959, 36, 491-501.

Edmund, N. Diaries for better writing? Elementary School Journal, $1963,63,270-272$. 
Eldredge, C. A study of the relationship between the oral and written composition of third grade children. Unpublished doctoral dissertation, University of Georgia, 1965.

Elkins, D. An experimental investigation of intensive reading and intensive writing to improve composition at the eighth grade level. Unpublished doctoral dissertation, American University, 1968.

Elsasser, N., \& John-Steiner, U. An interactionist approach to advancing literacy. Harvard Educational Review, 1977, 47, 355-369.

Emig, J. The composing processes of twelfth graders. Urbana, IL: National Council of Teachers of English, 1971.

Fellows, J. The influence of theme-reading and theme-correction on eliminating technical errors in the written compositions of ninth grade pupils. Studies in Education, 1932, 7.

Findlayson, D. The reliability of the marking of essays. British Journal of Educational Psychology, 1951, 21, 126-134.

Flower, L., \& Hayes, J. The dynamics of composing: Making plans and juggling constraints. In L. Gregg \& E. Steinberg (Eds.), Cognitive processes in writing. Hillsdale: Lawrence Erlbaum Assoc., 1980.

Ford, C. Developments in written composition during the primary school period. British Journal of Educational Psycholog.v. 1954, $24,38-45$.

Gee, T. The effects of written comment on expository composition. Unpublished doctoral dissertation, North Texas State University, 1970.

Geoghegan, P., \& Fitzgerald, J. Composition errors in letters written by children outside the school. Elementary School Journal, 1935, 35, 768-775.

Golub, L. Syntactic and semantic elements of students' oral and written discourse: Implications for teaching composition. Unpublished doctoral dissertation, Stanford University, 1968.

Golub, L. How American children learn to write. Elementary School Journal, 1974, 74, 236-247.

Golub, L., \& Frederick, W. An analysis of children's writing under different stimulus conditions. Research in the Teaching of English. 1970, 4, 168-181.

Gould, J. Experiments on composing letters: Some facts, some myths, and some observations. In L. Gregg \& E. Steinberg (Eds.), Cognitive process in writing. Hillsdale: Lawrence Erlbaum Assoc., 1980.

Graham, S., Hudson, F., Burdg, N., \& Carpenter, D. Educational personnel's perceptions of mainstreaming and resource room effectiveness. Psychology in the Schools, 1980, 17, 128-134.

Graham, S., \& Madan, A. Teaching letter formation. Academic Therapy, 1981, 16, 389-396.

Graham, S., \& Miller, L. Spelling research and practice: A unified approach. Focus on Exceptional Children, 1979, 12, 1-16.

Graham, S. \& Miller, L. Handwriting research and practice: A unified approach. Focus on Exceptional Children, 1980, 13, 1-16.

Graves, D. Sex differences in children's writing. Elementary English, 1973, 50, 1101-1106.

Graves, D. An examination of the writing processes of seven year old children. Research in the Teaching of English, 1975, 9, 227-241.

Graves, D. Balance the basics: Let them write. New York: Ford Foundation, 1978.

Groff, P. Children's oral language and their written composition. Elementary School Journal, 1978, 78, 181-191.

Harrell, L. A comparison of the development of oral and written language in school-age children. Monographs of the Society for Research in Child Development, 1957, 22, 1-77.

Harris, W. Teacher response to student writing: A study of the response patterns of high school teachers to determine the basis for teacher judgement of student writing. Research in the Teaching of English, 1977, 11, 175-185.

Hartog, P., \& Rhodes, E. The marks of examiners. New York: Macmillan, 1936.

Hayes, J. Cognitive psychology: Thinking and creating. Homewood, IL: Dorsey, 1978.
Hayes, J., \& Flower, L. Identifying the organization of writing processes. In L. Gregg \& E. Steinberg (Eds.), Cognitive processes in writing. Hillsdale: Lawrence Erlbaum Assoc., 1980.

Healy, K. A study of the factors involved in the rating of pupils' compositions. Journal of Experimental Education, 1935, 4, 50-53.

Heed, H. Children certainly do improve their writing skills. Clearing House, 1956, 30, 365-368.

Heider, F., \& Heider, G. Comparison of sentence structure of deaf and hearing children. Volta Review, 1941, pp. 364-367, 536-540, 599-604.

Hemreck, L. A comparison of the written language of learning disabled elementary children using the inventory of uritten expression and spelling. Unpublished manuscript, University of Kansas, 1979.

Heys, F. The theme-a-week assumption: A report of an experiment. English Journal, 1962, 51, 320-322.

Hill, J. An analysis of the writing of elementary children, grades 2 through 6, to determine the presence, frequency of use and development by grade level of specified literary devices. Unpublished doctoral dissertation, Indiana University, 1972.

Hoetker, J., \& Brossell, G. An EJ readership survey report. English Journal, 1980, 69, 13-19.

Hogan, T., \& Mishler, C. Judging the quality of student's writing: When and how. Elementary School Journal, 1979, 79, 142-146.

Howell, M. Differentiating variables in compositions of seven-year olds. Elementary School Journal, 1956, 57, 145-149.

Huck, S., \& Bounds, W. Essay grades: An interaction between graders' handwriting clarity and the neatness of examination papers. American Educational Research Journal, 1972, 9, 279-283.

Hudson, F. \& Graham, S. An approach to operationalizing the I.E.P. Learning Disability Quarterly, 1978, I, 13-32.

Hudson, F., Graham, S., \& Warner, M. Mainstreaming: An examination of the attitudes and needs of regular classroom teachers. Learning Disability Quarterly, 1979, 2, 58-62.

Hunt, K. Grammatical structures written at three grade levels. Research Report No. 3. Champaign, IL: National Council of Teachers of English, 1965.

Huxtable, Z. Criteria for judging thought content in written English. Journal of Educational Research, 1929, 19, 188-195.

Hwang, P. Errors and improvement in rating English compositions by means of a composition scale. Teachers College Contributions to Education, No. 417. New York: Teachers College, Columbia University, 1930.

Jacobs, G. When children think. New York: Teachers College Press, Columbia University, 1970.

Johnson, L. Children's writing in three forms of composition. Elementary English, 1967, 44, 265-269.

Keogh, B., \& Glover, A. The generality and durability of cognitive training effects. Exceptional Education Quarterly, 1980, I, 75-82.

Kincaid, G. Some factors affecting variations in the quality of a students' writing. Unpublished doctoral dissertation, Michigan State University, 1953.

Klein, S., \& Hart, F. Chance and systematic factors affecting essay grades. Journal of Educational Measurement, 1968, 5, 197-206.

Koch, K. Wishes, lies, and dreams. New York: Chelsea House, 1970.

Kohl, H. Thirty-six children. New York: Signet Books, 1967.

Kono, E. An analysis of certain grammatical elements in the written compositions of seventh and ninth grade students who speak the Hawaiian dialect. Unpublished doctoral dissertation, University of Denver, 1972.

Kraetsch, G. The effects of oral instructions and training on the expansion of written language. Learning Disability Quarterly, $1981,4,82-90$.

Kraus, S. The teaching of written composition in the public schools: A summary of research. University of Oregon Curriculum Bulletin. $1959,15$.

LaBrant, L. A study of certain language developments in children in grades four to twelve, inclusive. Genetic Psychological Monographs, 1933, 14, 387-491. 
Laird, C., Gorrell, R., \& Pflug, R. A basic course in modern English. Englewood Cliffs, NJ: Prentice-Hall, 1963.

LeFevre, C. Linguistics, English and the language arts. Boston: Allyn \& Bacon, 1970.

Leinhart, G., Zigmond, N., \& Cooley, W. W. Reading instruction and its effects. Paper presented at the annual meeting of the American Educational Research Association, Boston, April, 1980.

Lemon, B., \& Buswell, G. Oral and written expression in grade nine. School Review, 1943, 51, 544-549.

Lewis, H., \& Lewis, E. Written language performance of sixth-grade children of low socioeconomic status from bilingual and monolingual backgrounds. Journal of Experimental Education, 1965, 33, 237-242.

Littwin, $\dot{M}$. An experimental investigation of the effect of presentation upon the imaginative quality of descriptive writing among elementary-school pupils. Journal of Experimental Education, 1935, 4, 44-49.

Loban, W. The language of elementary school children. Champaign, IL: National Council of Teachers of English, 1963.

Lorge, I., \& Kruglov, L. The relation between merit of written expression and intelligence. Journal of Educational Research, 1951, 44, 507-519.

Macrorie, K. Uptaught. New York: Hayden Press, 1970.

Maize, R. Two methods of teaching English composition to retarded college freshmen. Journal of Educational Psychology, 1954, 45, 22-28.

Maloney, H. An identification of excellence in expository composition performance in a selected $9 A$ population with an analysis of reasons for superior performance. Unpublished doctoral dissertation, Columbia University, 1968.

Mann, M. The quantitative differentiation of samples of written language. Psichological Monographs, 1944, 56, 41-74.

Markham, L. Influence of handwriting quality on teacher evaluation of written work. American Educational Research Journal, 1976, 13, 277-283.

Marshall, J. Composition errors and essay examination grades reexamined. American Educational Research Journal, 1967, 4, 375-385.

Marshall, J., \& Powers, J. Writing neatness, composition errors, and essay grades. Journal of Educational Measurement, 1969, 6. 97-101.

Martellock, H. A psycholinguistic description of the oral and written language of a selected group of middle school children. Unpublished doctoral dissertation. Wayne State University, 1971.

Martin, W. Applying and exploring the Diederich method of measuring growth in writing ability in a high school. Unpublished doctoral dissertation, University of Iowa, 1970.

Mathews, E., Larsen, R., \& Gibbon, B. Experimental investigation of the relation between reading training and achievement in college composition classes. Journal of Educational Research, 1945, 38, 499-505.

May, F., \& Tabachnick, R. Three stimuli for creative writing. Elementary School Journal, 1966, 67, 88-94.

Meckel, H. Research on teaching composition and literature. In N. Gage, (Ed.), Handbook of research on teaching. Chicago: Rand McNally, 1963.

Meichenbaum, D. Cognitive behavior modification with exceptional children: A promise yet unfulfilled. Exceptional Education Quarterly, 1980, 1, 83-88.

Meisterheim, M. $\mathrm{R}_{\mathrm{X}}$ for helping Johnny write better. Elementary School Journal, 1977, 78, 5-8.

Mellon, J. Transformational sentence-combining: A method for enhancing the development of syntactic fluency in English composition. Research Report No. 10. Urbana, IL: National Council of Teachers of English, 1969.

McCarthy, D. Language development in children. In L. Carmichel (Ed.), Manual of child psychology (2nd ed.). New York: John Wiley \& Sons, 1954.
McClellan, J. Creative writing characteristics of children. Unpublished doctoral dissertation, University of Southern California, 1956.

McColly, W. What does educational research say about the judging of writing ability? Journal of Educational Research, 1970, 64, 148156.

McColly, W., \& Remstad, R. Comparative effectiveness of composition skills learning activities' in the secondary school. Research Report No. 1528. University of Wisconsin: USOE Cooperative Research Project, 1963.

McColly, W., \& Remstad, R. The dimensions of composition annotation. Research Report No. 216. Oswego: University of New York, USOE Cooperative Research Project, 1965.

McLean, H. A comparison of selected aspects of the oral and written language of fourth, fifth, and sixth grade students. Unpublished doctoral dissertation, University of Iowa, 1964.

Miller, B., \& Ney, J. The effect of systematic oral exercises on the writing of fourth-grade students. Research in the Teaching of English, 1968, 2, 44-61.

Moffett, J. Teaching the universe of discourse. New York: Houghton Mifflin, 1968.

Moran, M. A comparison of formal features of written language of learning disabled, low-achieving and achieving secondary students. Research Report No. 34. Lawrence, KS: Kansas Institute for Research in Learning Disabilities, 1981.

Moran, M., \& Vogel, S. Written language disorders in learning disabled college students: A preliminary report. In W. Cruickshank \& J. Learner (Eds.), Coming of age, vol. 3: The best of ACLD. Syracuse, NY: Syracuse University Press, in press.

Myers, M. Five approaches to the teaching of writing. Learning, 1978, $6,38-45$

Myklebust, H. Development and disorders of written language, vol. 2: Studies of normal and exceptional children. New York: Grune \& Stratton, 1973.

National Assessment of Educational Progress. Writing mechanics, 1966-1974: A capsule description of changes in writing mechanics. Report No. 05. W-01. Denver, CO: National Assessment of Educational Progress, 1975.

National Council of Teachers of English. Composition: A position statement. Elementary English, 1975, 52, 194-196.

Nelson, L. Inquiry - Into the influence of the assigned topic on written language. California Journal of Educational Research, $1965,16,100-107$.

Noyes, E. Essay and objective tests in English. College Board Review, $1963,49,7-10$.

Odell, L. Teaching writing by teaching the process of discovery: An interdisciplinary enterprise. In L. Gregg \& E. Steinberg (Eds.), Cognitive processes in writing. Hillsdale: Lawrence Erlbaum Assoc., 1980.

Odom, R. Capitalization and punctuation: A diagnostic test. California Journal of Educational Research, 1964, 15, 68-75.

O'Donnell, R., Griffin, W., \& Norris, R. Syntax of kindergarten and elementary school children: A transformational analysis. Research Report No. 8. Champaign, IL: National Council of Teachers of English, 1967.

Oftedal, L. Picture writing. Elementary School Journal, 1948, 49, $37-46$.

O'Hare, F. Sentence-combining: Improving students' writing without formal grammar instruction. Research Report No. 15. Urbana, IL: National Council of Teachers of English, 1973.

Page, E. The analysis of essays by computer. USOE Research Project No. 6-1318. Storrs, CT: University of Connecticut, 1968.

Patten, J. Personality patterns related to written expression. Unpublished doctoral dissertation, Stanford University, 1950.

Pave, M. Mass. students don't rite so good. Boston Globe, Tuesday, September 25, 1979.

Pearson, $\mathrm{R}$. The test fails as an entrance examination. College Board Review, 1963, 25, 2-9.

Perron, J. Composition and cognition. English Education, 1979, 10, 144-154. 
Pettigrew, J., Tefft, N., \& Van Nostrand, A. Functional writing: Secondary school edition. Providence, RI: Center for Research in Writing, 1977.

Poley, l. Variety in sentence-structure: Its relation to technical excellence in composition and to intelligence. Elementary English Review, 1929, 6, 126-128.

Pooley, R. Contributions of research to the teaching of English. English Journal, 1948, 37, 170-175.

Poplin, M., Gray, R., Larsen, S., Banikowski, A., \& Mehring, T. A comparison of components of written expression abilities in learning disabled and non-learning disabled students at three grade levels. Learning Disability Quarterly, 1980, 3, 46-53.

Poteet, J. Characteristics of written expression of learning disabled and non-learning disabled elementary school students. Diagnostique, 1979, 4, 60-74.

Raybern, J. An investigation of selected syntactic differences present in the oral and written language of lower socioeconomic status black third and fifth grade students. Unpublished doctoral dissertation, Indiana University, 1974.

Rodrigues, R. A comparison of the written and oral English syntax of Mexican American and anglo American monolingual fourth and ninth grade students. Unpublished doctoral dissertation, University of New Mexico, 1974.

Rondinella, O. An evaluation of subjectivity of elementary school teachers in grading handwriting. Elementary English, 1963, 40 , 531-532.

Rothstein, R. A comparison of the teaching of composition using literature as a model with a program for the writing of an informal essay. Unpublished doctoral dissertation, University of Colorado, 1970.

San Jose, C. Grammatical structures in four modes of writing at fourth grade level. Unpublished doctoral dissertation, Syracuse University, 1972.

Scannell, D., \& Marshall, J. The effect of selected composition errors on the grades assigned to essay examinations. American Educational Research Journal, 1966, 3, 125-130.

Scarda malia, M., Bereiter, C., \& McDonald, J. Role-taking in written communication investigated by manipulating anticipatory know edge. Paper presented at the biennial meeting of the Society for Research in Child Development, New Orleans, March 1977.

Schaeffer, B. Skill integration during cognitive development. In A. Kennedy \& A. Witkes (Eds.), Studies in long term memory. London: John Wiley \& Sons, 1975.

Schiff, P. Problem solving and the composition model: Reorganization, manipulation, analysis. Research in the Teaching of English, 1978, 12, 203-210.

Schneider, V. A study of the effectiveness of emphasizing the teaching of reading skills to improve composition skills in remedial English classes at Kansas City Kansas Community Junior College. Unpublished doctoral dissertation, University of Kansas, 1970.

Schonell, F. Backwardness in the basic subjects: Edinburg: Oliver \& Boyd, 1942.

Sedlak, R., \& Cartwright, G. Written language abilities of EMR and nonretarded children with the same mental age. American Journal of Mental Deficiency, 1972, 77, 95-99.

Shanahan, T. The writing crisis: A survey and solution. Phi Delta Kappan, 1979, 61, 206-217.

Shanahan, T. A cannonical correlational analysis of learning to read and learning to write: An exploratory analysis. Paper presented at the 26th Annual International Reading Association Convention, New Orleans, 1981.

Shaw, R. Out of the mouths of babes: A new way to teach the young. Atlantic Monthly, 1934, 154, 154-166.

Silverman, R., Zigmond, N., Zimmerman, J., \& Vallecorsa, A. Improving written expression in learning disabled students. Topics in Language Disorders, 1981, 1, 91-99.

Simmons, A. Comparison of written and spoken language from deaf and hearing children at five age groups. Unpublished doctoral dissertation, Washington University, 1963.
Smart, D., \& Ollila, L. The effect of sentence-combining practice on written compositions and reading comprehension. Alberta Journal of Educational Research, 1978, 24, 113-120.

Smith, W., \& Swan, B. Adjusting syntactic structures to varied levels of audience. Journal of Experimental Education. 1978, 46, 29-34.

Sofell, C. A comparison of the use of imposed with self-chosen subjects in a creative writing program. Unpublished master's thesis, University of Pittsburgh, 1929.

Soloff, S. Effect of non-content factors on the grading of essays. Graduate Research in Education and Related Disciplines, 1973,6, 44-54.

Sponsler, M. The effectiveness of literary models in the teaching of written composition. Unpublished doctoral dissertation, University of Maryland, 1971.

Stallard, C. An analysis of the writing behavior of good student writers. Research in the Teaching of English, 1974, 8, 206-218.

Stalnaker, J. Sex differences in the ability to write. School and Societ!, 1941, 54, 532-535.

Starch, D., \& Elliott, E. Reliability of the grading of high school work in English. School Review, 1912, 20, 442-457.

Sterrett, R. A comparison of the written language ability of educable mentally retarded and normal adolescents. Unpublished manuscript, University of Pittsburgh, 1965.

Stevens, A. The effects of positive and negative evaluation on the written composition of low performing high school students. Unpublished doctoral dissertation, Boston University, 1973.

Stewart, M. Syntactic maturity from high school to university: A first look. Research in the Teaching of English, 1978, I2, 37-42.

Strickland, R. Implication of research in linguistics for elementary teaching. Elementary English, 1963, 40, 168-171.

Suberman, J., \& Rosenberg, H. Basic composition. Englewood Cliffs, NJ: Prentice-Hall, 1963

Sutton, J., \& Allen, T. The effect of practice and evaluation on improvement in written composition. Research Report No. 1993. Deland, FL: Stetson University, 1964.

Swenson, E., \& Caldwell, C. The process of communication in children's letters. Elementary' School Journal, 1948, 49, 79-88.

Taylor, W., \& Hoedt, K. The effect of praise upon the quality and quantity of creative writing. Journal of Educational Research, $1966,60,80-83$.

Van Bruggen, J. Factors affecting regularity of the flow of words during written composition. Journal of Experimental Education, $1946,15,133-155$.

Van Houten, R., \& McKillop, C. An extension of the effects of the performance feedback system with secondary school students. Psychology in the Schools, 1977, 14, 480-483.

Vernon, P., \& Millican, G. A further study of the reliability of English essays. British Journal of Statistical Psychology, 1954, 7, 65-174.

Waldschmidt, E. Pilot studies in composition: Their effects upon students and participating English teachers. Unpublished doctoral dissertation, University of Illinois, 1973.

Whale, K., \& Robinson, S. Modes of students' writings: A descriptive study. Research in the Teaching of English, 1978, 12, 349-355.

Wheeler, A. A study to determine the errors that appear in written work of rural and urban pupils in certain school systems in Kentucky. Journal of Experimental Education. 1940, 8, 385-398.

Wheeler, F. An experimental study of means to improve writing. Journal of Secondary Education, 1965, 40, 331-335.

Wiggins, R. A study of the influence of oral instruction on students ability in written sentence structure. Unpublished doctoral dissertation, University of South Carolina, 1968.

Wilson, L. Creative writing in a first grade. Elementary English. 1949, 26. 241-249.

Wilson, L. A study of some influencing factors upon and the nature of young children's written language. Journal of Experimental Education, 1963, 31, 371-380.

Witty, P., \& Martin, W. An analysis of children's compositions written in response to a film. Elementary English, 1957, 34, 158-163. 
Woodward, J., \& Phillips, A. Profile of the poor writer - The relationship of selected characteristics of poor writing in college. Research in the Teaching of English, 1967, 1, 41-53.

Wyatt, N. A study of the relationship of extensive reading to certain writing skills of a selected group of sixth-grade children. University of Kansas Bulletin of Education, 1961, 16, 13-18.

Zanotti, R. A study of the use of the tape recorder as an aid to written composition at the sixth-grade level. Unpublished doctoral dissertation, State University of New York at Buffalo, 1970.

\section{ALERT}

June 11-13, 1982

Association for the Gifted (TAG)

Regional Conference on Gifted Minorities

Tucson, Arizona

Write: Dr. June Maker, Dept. of Special Education, University of Arizona, Tucson, AZ 85721

June 14-18, 1982

TAG Institute on Gifted Minorities

Tucson, Arizona

Write: Dr. June Maker, Dept. of Special Education, University of Arizona, Tucson, AZ 85721

\section{NEW BOOK}

PARTNERS: A Guide to Working with Schools for Parents of Children with Special Instructional Needs by David L. Lillie and Patricia A. Place

This practical publication is intended as a guide to the law and to children's and parents' rights. It offers help in identifying the special needs child and looks at schools' screening techniques and placement options. Each chapter includes an introduction, objectives, lessons, and accompanying exercises. Specific topics include current laws, young children and infants, choosing the right program, evaluation, IEPs, surrogate parents, homeschool relations, and other pertinent information.

It is more than a guide; it is also a workbook. Step-bystep instructions let users test their knowledge and rate their effectiveness with both the child and school personnel. Basically, this book offers practical information and strategies that allow parents to do the best possible job in ensuring an appropriate educational opportunity for their special needs children.

The publication is available from Scott, Foresman, \& Co., 1640 Fifth St., Santa Monica, CA 90401. 